\title{
A New Epi-neoverrucosane-type Diterpenoid from the Liverwort Pleurozia subinflata in Borneo
}

\author{
Takashi Kamada ${ }^{1,2}$ (D) Mary Lyn Johanis ${ }^{2} \cdot$ Shean-Yeaw $\mathrm{Ng}^{2} \cdot$ Chin-Soon Phan ${ }^{2} \cdot$ Monica Suleiman ${ }^{2}$. \\ Charles S. Vairappan ${ }^{2}$
}

Received: 9 January 2020 / Accepted: 6 February 2020 / Published online: 15 February 2020

(C) The Author(s) 2020

\begin{abstract}

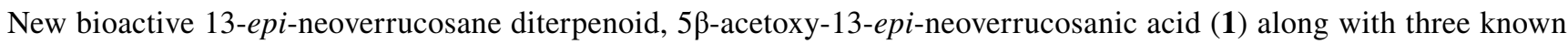
secondary metabolites, 13-epi-neoverrucosan-5 $\beta$-ol (2), chelodane (3) and (E)- $\beta$-farnesene (4) were isolated from the $\mathrm{MeOH}$ extract of east Malaysia's liverwort Pleurozia subinflata. The chemical structure of new compound was elucidated by the analyses of its spectroscopic data (FTIR, NMR and HR-ESI-MS). These epi-neoverrucosane-type compounds seem to be notable chemosystematic markers for $P$. subinflata in Borneo. Compound $\mathbf{3}$ was widespread in marine sponges however this is the first record for $\mathbf{3}$ to be found in liverwort. These metabolites were tested for their antifungal potentials against selected fungi from the marine environment. Compound $\mathbf{1}$ exhibited effective antifungal activity against Lagenidium thermophilum.
\end{abstract}

\section{Graphic Abstract}

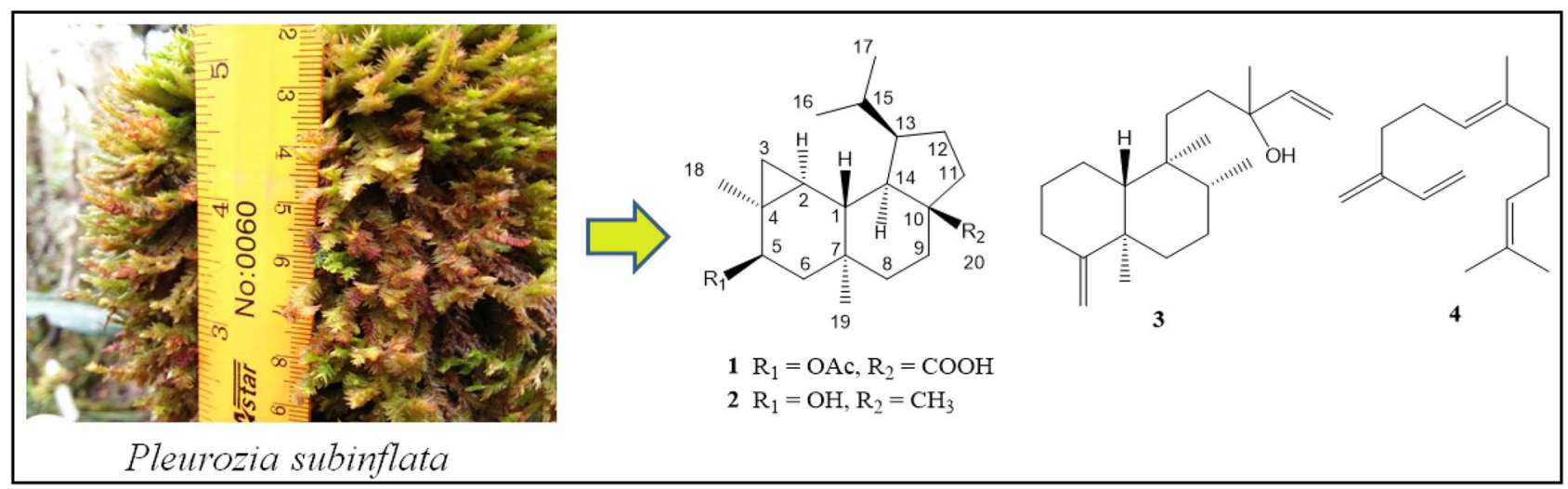

Keywords Epi-neoverrucosane $\cdot$ Diterpenoid $\cdot$ Pleurozia subinflata $\cdot$ Liverwort · Borneo

Electronic supplementary material The online version of this article (https://doi.org/10.1007/s13659-020-00232-6) contains supplementary material, which is available to authorized users.

Takashi Kamada

takashi.kamada800@gmail.com

1 Department of Materials and Life Science, Faculty of Science and Technology, Shizuoka Institute of Science and Technology, 2200-2 Toyosawa, Fukuroi, Shizuoka 437-8555, Japan

2 Institute for Tropical Biology and Conservation, Universiti Malaysia Sabah, 88400 Kota Kinabalu, Sabah, Malaysia

\section{Introduction}

Liverworts are the largest group of pioneering land plants which arose during the adaptation of plants from marine to terrestrial environment [1]. They produced terpenoids and/ or aromatic compounds as their major lipophilic constituents [2-5]. Many types of sesquiterpenoids from liverworts are the enantiomer to those metabolites from higher plants [6]. While, diterpenoids such as clerodanes, dolabellanes, fusicoccanes, kauranes, labdanes, pimaranes and others were found in numerous liverworts [6]. Recently several bioactive 
cyathane diterpenoids were discovered $[7,8]$. Cyathane is precursor structure for biosynthesis of the verrucosanetype diterpenoid, a fused 3,6,6,5-tetracyclic carbon skeleton [9]. First verrucosane diterpenoid was isolated from Mylia verrucosa [10]. Later, some analogs such as neoverrucosane-, homoverrucosane-, epi-neoverrucosane- and epi-homoverrucosane-type were reported [11-13]. The latest $e p i$-neoverrucosane analog was reported in 2013 [14]. Hereby, we report yet another new epi-neoverrucosane diterpenoid, 5 $\beta$-acetoxy-13-epi-neoverrucosanic acid (1) was isolated, along with three known secondary metabolites, 13-epi-neoverrucosan-5 $\beta$-ol (2), chelodane (3) and (E)- $\beta$ farnesene (4) from east Malaysia's liverwort Pleurozia subinflata (Fig. 1).

Besides, liverworts have long been used as traditional medicine by the indigenous people in some parts of China. In the past half-century, Prof. Yoshinori Asakawa (Tokushima Bunri University, Japan) has begun to study the chemical composition of liverworts collected from Asia, Europe and South America, many of which have reported to have diverse chemical structures and exhibited numerous biological activities [2, 6]. Thus, research focusing on the biological activity of liverwort and industrial use are significant. Our research examined the antifungal effects of the four isolated compounds against selected fungi separated marine organisms.

\section{Results, Discussion and Conclusion}

Compound 1 was isolated as colorless oil and analyzed for the molecular formula $\mathrm{C}_{22} \mathrm{H}_{34} \mathrm{O}_{4}$ by HR-ESI-MS [M $-\mathrm{H}]^{-}$ion at $m / z$ 361.2391. The ${ }^{13} \mathrm{C}$ and ${ }^{1} \mathrm{H}$ NMR data (Table 1) indicated the presence of an isopropyl unit at $\delta_{\mathrm{C}} 31.1,23.2$ and $22.3 ; \delta_{\mathrm{H}} 1.51-1.55,1.00$ and 0.78 , one carboxylic carbon at $\delta_{\mathrm{C}} 183.0$, an acetoxy unit at $\delta_{\mathrm{C}} 171.5$, $21.5 ; \delta_{\mathrm{H}} 2.04$, one oxygenated methine at $\delta_{\mathrm{C}} 75.1 ; \delta_{\mathrm{H}} 5.28$, two tertiary methyls at $\delta_{\mathrm{C}} 25.5$ and $16.4 ; \delta_{\mathrm{H}} 1.12$ and 0.87 ,
Table $1{ }^{1} \mathrm{H}$ and ${ }^{13} \mathrm{C}$ NMR (600 and $150 \mathrm{MHz}$ ) data of $\mathbf{1}$ (in $\mathrm{CDCl}_{3}, \delta$ in ppm, $J$ in $\mathrm{Hz}$ ).

\begin{tabular}{|c|c|c|}
\hline No & $\delta_{\mathrm{C}}$ & $\delta_{\mathrm{H}}$ \\
\hline 1 & 44.1 & $2.20(1 \mathrm{H}, \mathrm{dd}, J=4.3,13.1)$ \\
\hline 2 & 26.7 & $0.65(1 \mathrm{H}, \mathrm{ddd}, J=4.1,4.1,8.3)$ \\
\hline 3 & 21.8 & $\begin{array}{l}0.69(1 \mathrm{H}, \mathrm{dd}, J=4.3,8.3) \\
0.56(1 \mathrm{H}, \mathrm{dd}, J=4.3,4.3)\end{array}$ \\
\hline 4 & 20.1 & \\
\hline 5 & 75.1 & $5.28(1 \mathrm{H}, \mathrm{dd}, J=7.6,10.7)$ \\
\hline 6 & 42.3 & $\begin{array}{l}1.76(1 \mathrm{H}, \mathrm{dd}, J=7.6,12.5) \\
0.84(1 \mathrm{H}, \mathrm{m})\end{array}$ \\
\hline 7 & 36.8 & \\
\hline 8 & 34.9 & $\begin{array}{l}1.51-1.55(1 \mathrm{H}, \mathrm{m}) \\
1.09-1.11(1 \mathrm{H}, \mathrm{m})\end{array}$ \\
\hline 9 & 32.3 & $\begin{array}{l}1.81-1.84(1 \mathrm{H}, \mathrm{m}) \\
1.59-1.62(1 \mathrm{H}, \mathrm{m})\end{array}$ \\
\hline 10 & 52.0 & \\
\hline 11 & 36.3 & $\begin{array}{l}2.45(1 \mathrm{H}, \mathrm{ddd}, J=1.4,8.9,11.6) \\
1.21-1.23(1 \mathrm{H}, \mathrm{m})\end{array}$ \\
\hline 12 & 27.5 & $\begin{array}{l}1.81-1.84(1 \mathrm{H}, \mathrm{m}) \\
1.51-1.55(1 \mathrm{H}, \mathrm{m})\end{array}$ \\
\hline 13 & 45.3 & $1.88(1 \mathrm{H}, \mathrm{m})$ \\
\hline 14 & 51.7 & $1.67(1 \mathrm{H}, \mathrm{dd}, J=7.6,13.1)$ \\
\hline 15 & 31.1 & $1.51-1.55(1 \mathrm{H}, \mathrm{m})$ \\
\hline 16 & 22.3 & $0.78(3 \mathrm{H}, \mathrm{d}, J=6.9)$ \\
\hline 17 & 23.2 & $1.00(3 \mathrm{H}, \mathrm{d}, J=6.9)$ \\
\hline 18 & 25.5 & $1.12(3 \mathrm{H}, \mathrm{s})$ \\
\hline 19 & 16.4 & $0.87(3 \mathrm{H}, \mathrm{s})$ \\
\hline 20 & 183.0 & \\
\hline $5-\mathrm{OAc}$ & 171.5 & \\
\hline & 21.5 & $2.04(3 \mathrm{H}, \mathrm{s})$ \\
\hline
\end{tabular}

six methylenes, four methines, and three quaternary carbons which corresponding well to HSQC spectrum. Based on these findings, six degrees of unsaturation was
Fig. 1 Chemical structures of 1-4

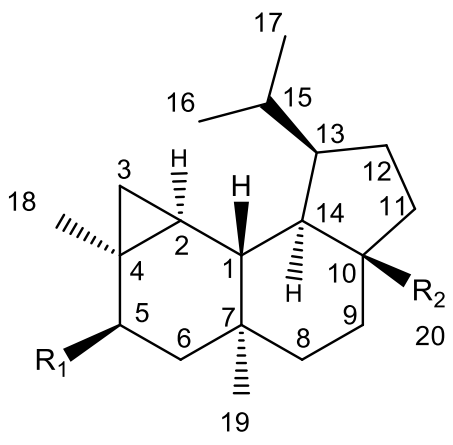

$1 \mathrm{R}_{1}=\mathrm{OAc}, \mathrm{R}_{2}=\mathrm{COOH}$

$2 \mathrm{R}_{1}=\mathrm{OH}, \mathrm{R}_{2}=\mathrm{CH}_{3}$

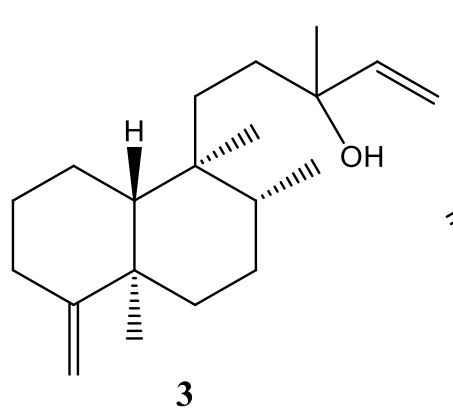<smiles>C=CC(=C)CCC=C(C)CCC=C(C)C</smiles>

4 
calculated from HR-ESI-MS, and it attributed to two carbonyl units and one tetracyclic ring for $\mathbf{1}$.

The ${ }^{1} \mathrm{H}-{ }^{1} \mathrm{H}$ COSY experiment revealed the spin systems as depicted by the bold lines in Fig. 2. In the HMBC spectrum, the three-bond correlations of $\mathrm{H}_{3}-\mathrm{C}(16)$ and $\mathrm{H}_{3}-\mathrm{C}(17)$ to the opposite carbons $\mathrm{C}(17)$ and $\mathrm{C}(16)$, and to $\mathrm{C}(13)$ and $\mathrm{C}(15)$, allowed the placement of isopropyl unit at $\mathrm{C}(13)$ which was further confirmed by ${ }^{1} \mathrm{H}-{ }^{1} \mathrm{H}$ COSY. The acetoxy unit at $\mathrm{C}(5)$ was confirmed by $\mathrm{HMBC}$ correlations between $\mathrm{H}-\mathrm{C}(5)$ to 5-OAc. The downfield shifted of ${ }^{13} \mathrm{C}$ and ${ }^{1} \mathrm{H}$ NMR at $\mathrm{C}(5)$ further supported this deduction. The HMBC correlations of $\mathrm{H}_{2}-\mathrm{C}(11)$ to $\mathrm{C}(20)$; and $\mathrm{H}-\mathrm{C}(14)$ to $\mathrm{C}(20)$ suggested the carboxylic carbon at $\mathrm{C}(10)$. These findings together with $\mathrm{HMBC}$ correlations of $\mathrm{H}_{3}-\mathrm{C}(18)$ to $\mathrm{C}(2), \mathrm{C}(3)$, $\mathrm{C}(4)$ and $\mathrm{C}(5)$; and $\mathrm{H}_{3}-\mathrm{C}(19)$ to $\mathrm{C}(1), \mathrm{C}(6), \mathrm{C}(7)$ and $\mathrm{C}(8)$ permitted establishment for the planar structure of $\mathbf{1}$ (Fig. 2).

The relative stereochemistry of $\mathbf{1}$ was deduced from the NOESY correlations (Fig. 2) and comparison of its chemical shift, coupling constants and NOE correlations with those of known analogs [10-14]. The NOE correlations of $\mathrm{H}-\mathrm{C}(5)$ to $\mathrm{H}_{2}-\mathrm{C}(6 \alpha)\left(\delta_{\mathrm{H}} 1.76\right), \mathrm{H}_{3}-\mathrm{C}(18)$ and $\mathrm{H}_{3}-\mathrm{C}(19)$; and $\mathrm{H}-\mathrm{C}(14)$ to $\mathrm{H}_{3}-\mathrm{C}(19)$ have suggested $\mathrm{H}-\mathrm{C}(5), \mathrm{H}-\mathrm{C}(14)$, $\mathrm{H}_{3}-\mathrm{C}(18)$ and $\mathrm{H}_{3}-\mathrm{C}(19)$ on $\alpha$ relative configuration. While, NOE correlations of $\mathrm{H}-\mathrm{C}(1)$ to $\mathrm{H}_{2}-\mathrm{C}(3 \beta)\left(\delta_{\mathrm{H}} 0.56\right)$ and $\mathrm{H}_{2}-\mathrm{C}(6 \beta)\left(\delta_{\mathrm{H}} 0.84\right)$ showed $\mathrm{H}-\mathrm{C}(1)$ must be on another face, $\beta$ relative configuration. The earlier NOE cross peak of $\mathrm{H}-\mathrm{C}(1)$ to $\mathrm{H}_{2}-\mathrm{C}(3)\left(\delta_{\mathrm{H}} 0.56\right)$ has led to the assignment of $\mathrm{H}_{2}-\mathrm{C}(3)\left(\delta_{\mathrm{H}} 0.56\right)$ on $\beta$ configuration, therefore $\mathrm{H}_{2}-\mathrm{C}(3)$ $\left(\delta_{\mathrm{H}} 0.69\right)$ must be on $\alpha$ configuration. With this finding, the configuration at $\mathrm{H}-\mathrm{C}(2)$ can be assigned based on vicinal coupling constants of cyclopropane unit between $\mathrm{H}-\mathrm{C}(2)$ and $\mathrm{H}_{2}-\mathrm{C}(3 \alpha)\left({ }^{3} J_{2-3 \alpha}=8.3 \mathrm{~Hz}\right)$ and between $\mathrm{H}-\mathrm{C}(2)$ and $\mathrm{H}_{2}-\mathrm{C}(3 \beta)\left({ }^{3} J_{2-3 \beta}=4.3 \mathrm{~Hz}\right)$. These coupling constant values suggested $\mathrm{H}-\mathrm{C}(2)$ has a cis relationship with $\mathrm{H}_{2}-\mathrm{C}(3 \alpha)$ within the cyclopropane unit, therefore $\alpha$ configuration was assigned for $\mathrm{H}-\mathrm{C}(2)$. While, the carboxyl unit at $\mathrm{C}(10)$ was assigned on $\beta$ configuration due to a trans-fused at $\mathrm{C} / \mathrm{D}$ ring junction. Thus, the relative configurations of $1 R^{*}, 2 S^{*}, 4 S^{*}$, $5 R^{*}, 7 S^{*}, 10 S^{*}$ and $14 R^{*}$ were determined as identical to those of known analogs of neoverrucosane and epi-neoverrucosane [10-14]. To distinguish epi-neoverrucosane from neoverrucosane, the NOE correlations of $\mathrm{H}-\mathrm{C}(1)$ to $\mathrm{H}-\mathrm{C}(15)$ and $\mathrm{H}_{3}-\mathrm{C}(17)$; and $\mathrm{H}-\mathrm{C}(13)$ to $\mathrm{H}-\mathrm{C}(14)$, showed 13-isopropyl unit to $\mathrm{H}-\mathrm{C}(14)$ has a trans configuration, suggested a epi-neoverrucosane. Furthermore, similar NOE correlations of $\mathrm{H}-\mathrm{C}(1)$ to $\mathrm{H}-\mathrm{C}(15)$; and $\mathrm{H}-\mathrm{C}(13)$ to $\mathrm{H}-\mathrm{C}(14)$ were observed in 12-acetoxy-13-epi-neoverrucosann-5-one [14]. On the contrary, these NOE were not observed in neoverrucosane-type, neoverrucosan- $5 \beta, 9 \beta$-diol, instead $\mathrm{H}-\mathrm{C}(13)$ to $\mathrm{H}-\mathrm{C}(20)$ was detected [15]. Thus, the structure 1 was established without confusion. The configuration of isopropyl unit at $\mathrm{C}(13)$ generated during formation of tricyclic system (Fig. 3) determined the biosynthesis of neoverrucosane or epi-neoverrucosane [9]. To the best of our knowledge, compound $\mathbf{1}$ was considered as first discovery of 13-epi-neoverrucosane that containing a carboxyl moiety or even among related skeletons such as verrucosane and neoverrucosane. The methyl at $\mathrm{C}(20)$ of $\mathbf{1}$ might have followed a three-step oxidation, via a hydroxyl and carbonyl, to the corresponding carboxylic acid [16], as shown in the purposed biosynthetic pathway (Fig. 3).

The known compounds were identified as 13-epineoverrucosan-5 $\beta$-ol (2) [11], chelodane (3) [17], and (E)$\beta$-farnesene (4) [18], after compared its spectroscopic data with published literatures. The tetracyclic diterpenes are relatively rare in nature, and mainly found in the species of Plagiochila, Jamesoniella and Fossombronia [6]. However, we found epi-neoverrucosane-type diterpene derivatives ( 1 and 2) from east Malaysia's liverwort, Pleurozia subinflata. These secondary metabolites seem to be the good chemosystematic markers for $P$. subinflata in Borneo. Compound $\mathbf{3}$ was widespread in marine sponges such as Chelonaplysilla erecta, Raspailia sp. and even in Sigmosceptrella sp. [17, $19,20]$. However, this is the first record for 3 found in liverwort. Compound 4 was the most common farnesane-type sesquiterpene in liverworts. It was distributed throughout more than 20 Jungermanniales and Pleuroziales species including Pleurozia [6].
Fig. $2{ }^{1} \mathrm{H}-{ }^{1} \mathrm{H}$ COSY, key HMBC and NOE correlations of 1
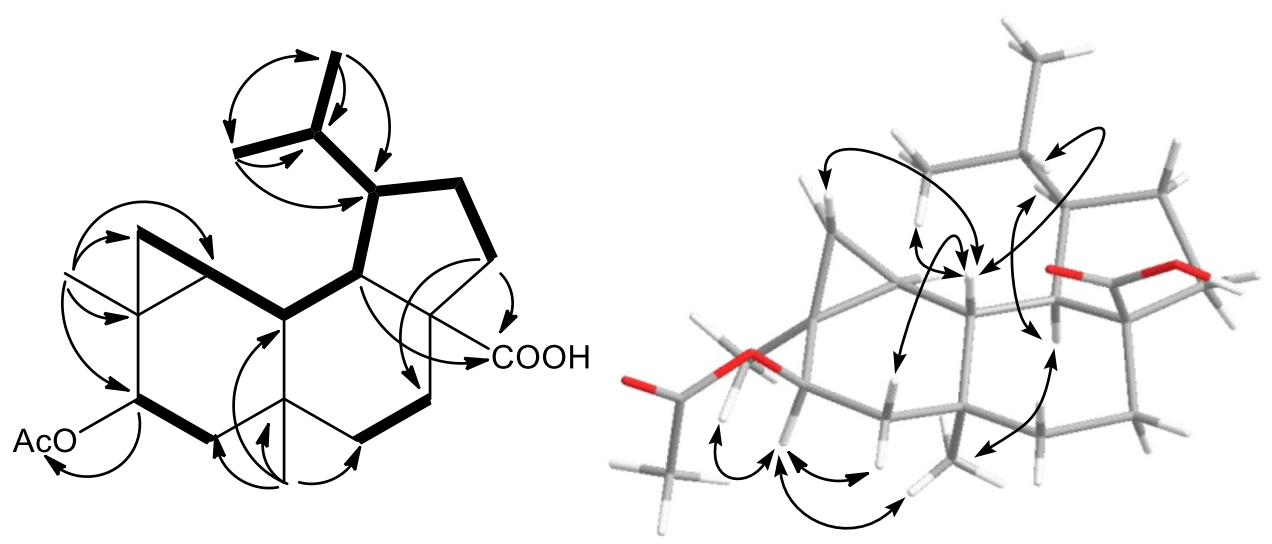


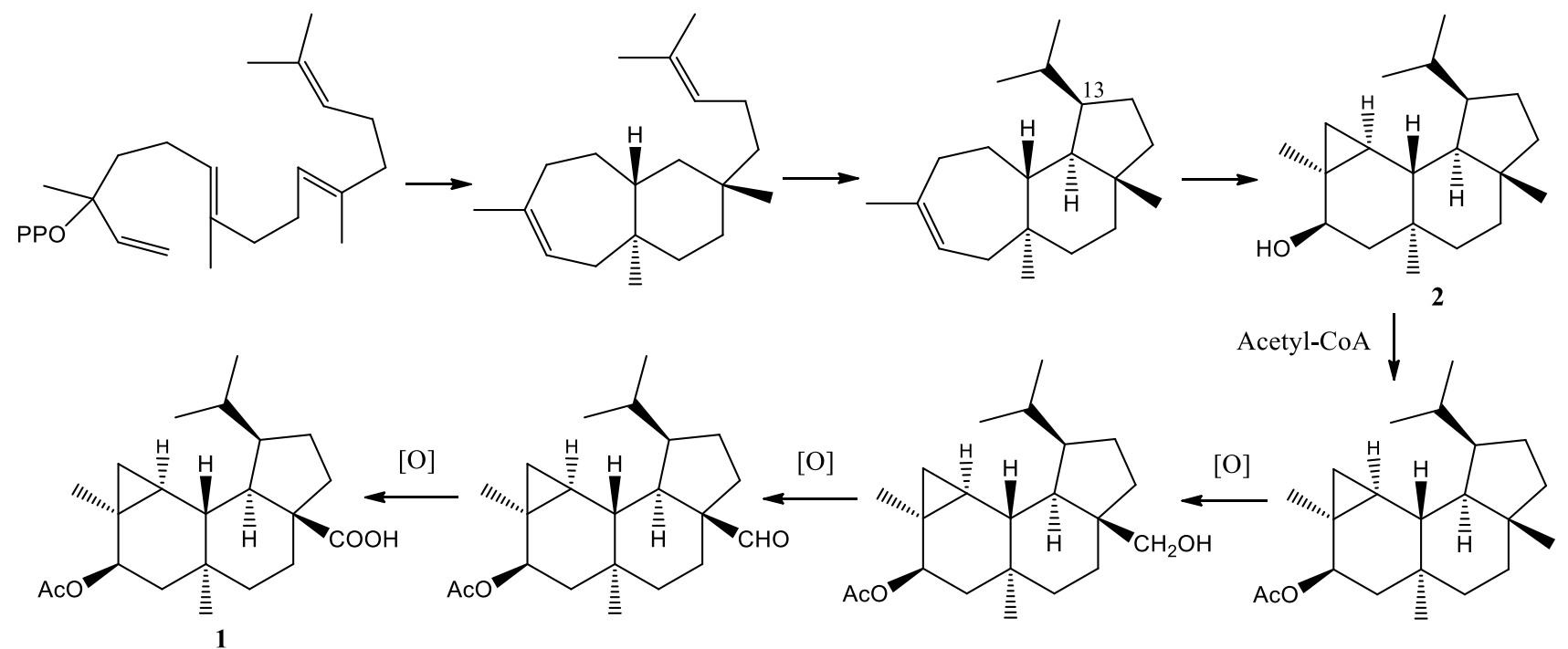

Fig. 3 Proposed biosynthetic pathway of $\mathbf{1}$

Table 2 The MIC $(\mu \mathrm{g} / \mathrm{mL})$ of $\mathbf{1}-\mathbf{4}$ against six fungal strains

\begin{tabular}{|c|c|c|c|c|}
\hline \multirow[t]{2}{*}{ Strains } & \multicolumn{4}{|c|}{$\mathrm{MIC}(\mu \mathrm{g} / \mathrm{mL})$} \\
\hline & 1 & 2 & 3 & 4 \\
\hline L. thermophilum & 12.5 & 100.0 & 100.0 & $>100.0$ \\
\hline H. sabahensis & 50.0 & $>100.0$ & $>100.0$ & $>100.0$ \\
\hline F. moniliforme & $>100.0$ & $>100.0$ & $>100.0$ & $>100.0$ \\
\hline F. oxysporum & $>100.0$ & $>100.0$ & $>100.0$ & $>100.0$ \\
\hline F. solani & $>100.0$ & $>100.0$ & $>100.0$ & $>100.0$ \\
\hline O. humicola & $>100.0$ & $>100.0$ & $>100.0$ & $>100.0$ \\
\hline
\end{tabular}

Positive control: itraconazole MIC $2.0 \mu \mathrm{g} \mathrm{mL}^{-1}$

Compounds 1-4 were evaluated its biological potentials against fungal strains isolated from the Bornean ocean, Lagenidium thermophilum IPMB 1401, Haliphthoros sabahensis IPMB 1402, Fusarium moniliforme NJM 8995, Fusarium oxysporum NJM 0179, Fusarium solani NJM 8996 and Ochroconis humicola NJM 1503 (Table 2). The minimum inhibition concentration (MIC) values of compound $\mathbf{1}$ against $L$. thermophilum and $H$. sabahensis were 12.5 and $50 \mu \mathrm{g} / \mathrm{mL}$, respectively. While, compounds 2 and 3 showed MIC values of $100 \mu \mathrm{g} / \mathrm{mL}$ against $L$. thermophilum. Compound 4 was inactive ( $>100 \mu \mathrm{g} / \mathrm{mL}$ ) against the tested fungi.

In conclusion, this is the first time ever since 2013 of the last epi-neoverrucosane being discovered from nature. A new 13-epi-neoverrucosane diterpenoid, $5 \beta$-acetoxy-13epi-neoverrucosanic acid (1) along with three known secondary metabolites, 13-epi-neoverrucosan-5 $\beta$-ol (2), chelodane (3) and $(E)$ - $\beta$-farnesene (4) were found in east Malaysia's liverwort Pleurozia subinflata. Compound
1 exhibited effective antifungal activity (MIC values of $12.5 \mu \mathrm{g} / \mathrm{mL}$ ) against Lagenidium thermophilum.

\section{Experimental Section}

\subsection{General Experimental Procedures}

Optical rotation was taken on the automatic polarimeter (AUTOPOL IV automatic polarimeter) in chloroform solutions at $28{ }^{\circ} \mathrm{C}$. IR spectrum was recorded on the FTIR spectroscopy (Perkin Elmer). NMR spectra were recorded on the $600 \mathrm{MHz}$ FT-NMR (Jeol) using deuterated chloroform $\left(\mathrm{CDCl}_{3}\right)$ with tetramethylsilane (TMS) as the internal standard. MS spectra were obtained using LC-ESIIT-TOF-MS (Shimadzu). For preparative TLC, Merck Kieselgel $60 \mathrm{~F}_{254}$ was used and Kieselgel 60 was used for column chromatography. Purification was performed using high performance liquid chromatography (LC-10 AT, Shimadzu) equipped with UV detector.

\subsection{Biological Materials}

Specimens of P. subinflata (M. Suleiman \& S. $-Y$. Ng 5946) were collected from Mount Trus Madi (5 $5^{\circ} 33^{\prime} 13.1^{\prime \prime} \mathrm{N}$, $116^{\circ} 30^{\prime} 41.9^{\prime \prime}$ E), Sabah, Malaysia in August 2015. The specimens were identified based on external morphology by the fifth author. A voucher specimen (BORHB0026) is deposited in the BORNEENSIS Herbarium at Institute for Tropical Biology and Conservation (ITBC), Univeristi Malaysia Sabah (UMS). 


\subsection{Extraction and Isolation}

The air-dried liverwort specimens (42 g) were extracted using $100 \%$ methanol $(\mathrm{MeOH})(1.0 \mathrm{~L} \times 3$ each for two days). The crude extract was partitioned between distilled water $(150 \mathrm{~mL})$ and ethyl acetate $($ EtOAc) $(50 \mathrm{~mL} \times 3)$. After removal of the organic solvent, the EtOAc fraction $(500 \mathrm{mg}$ ) was chromatographed on a Si gel column using hexane (Hex) and EtOAc system as eluent with increasing polarity (Hex/EtOAc: 9:1, 8:2, 7:3, 5:5, 100\% EtOAc) to yield five fractions, $1-5$. Fraction $2(76 \mathrm{mg})$ was subjected to repeated preparative TLC with toluene to yield $\mathbf{2}(8.8 \mathrm{mg}), \mathbf{3}$ $(7.4 \mathrm{mg})$ and $4(15.4 \mathrm{mg})$. Fraction $3(60 \mathrm{mg})$ was subjected to repeated preparative TLC with hexane/EtOAc: 7:3, and the resulted sub-fraction was further purified by semi-preparative high performance liquid chromatography (HPLC) to yield $1(12.8 \mathrm{mg})$. The isolation was operated using a reverse phase $\mathrm{C}_{18}$ column $(5 \mu \mathrm{m}, 10 \mathrm{~mm} \times 250 \mathrm{~mm})$ measured at UV wavelength of $210 \mathrm{~nm}$ under gradient elution with the following conditions: $40-100 \%$ acetonitrile $(\mathrm{MeCN}) / \mathrm{H}_{2} \mathrm{O}$.

\subsubsection{3-Acetoxy-13-Epi-neoverrucosanic Acid (1)}

Colorless oil; $[\alpha]_{\mathrm{D}}^{28.0}+67.8\left(c=0.5, \mathrm{CHCl}_{3}\right) ; \mathrm{IR} \nu_{\max } 3488$, 3060, 1735 and $1712 \mathrm{~cm}^{-1} ;{ }^{1} \mathrm{H}$ NMR $\left(\mathrm{CDCl}_{3}, 600 \mathrm{MHz}\right) \delta$ $5.28(1 \mathrm{H}, \mathrm{dd}, J=7.6,10.7 \mathrm{~Hz}, \mathrm{H}-5), 2.45(1 \mathrm{H}$, ddd, $J=1.4$, $8.9,11.6 \mathrm{~Hz}, \mathrm{H}-11 \alpha), 2.20(1 \mathrm{H}, \mathrm{dd}, J=4.3,13.1 \mathrm{~Hz}$, $\mathrm{H}-1), 2.04(3 \mathrm{H}, \mathrm{s}, \mathrm{OAc}), 1.88(1 \mathrm{H}, \mathrm{m}, \mathrm{H}-13), 1.81-1.84$ $(1 \mathrm{H}, \mathrm{m}, \mathrm{H}-12 \alpha), 1.81-1.84(1 \mathrm{H}, \mathrm{m}, \mathrm{H}-9 \alpha), 1.76(1 \mathrm{H}, \mathrm{dd}$, $J=7.6,12.5 \mathrm{~Hz}, \mathrm{H}-6 \alpha), 1.67(1 \mathrm{H}, \mathrm{dd}, J=7.6,13.1 \mathrm{~Hz}$, $\mathrm{H}-14), 1.59-1.62(1 \mathrm{H}, \mathrm{m}, \mathrm{H}-9 \beta), 1.51-1.55(1 \mathrm{H}, \mathrm{m}, \mathrm{H}-8 \alpha)$, 1.51-1.55 (1H, m, H-12ß), 1.51-1.55 (1H, m, H-15), 1.21-1.23 (1H, m, H-11ß), 1.12 (3H, s, H-18), 1.09-1.11 $(1 \mathrm{H}, \mathrm{m}, \mathrm{H}-8 \beta), 1.00(3 \mathrm{H}, \mathrm{d}, J=6.9 \mathrm{~Hz}, \mathrm{H}-17), 0.87(3 \mathrm{H}, \mathrm{s}$, $\mathrm{H}-19), 0.84(1 \mathrm{H}, \mathrm{m}, \mathrm{H}-6 \beta), 0.78(3 \mathrm{H}, \mathrm{d}, J=6.9 \mathrm{~Hz}, \mathrm{H}-16)$, $0.69(1 \mathrm{H}, \mathrm{dd}, J=4.3,8.3 \mathrm{~Hz}, \mathrm{H}-3 \alpha), 0.65(1 \mathrm{H}, \mathrm{ddd}, J=4.1$, $4.1,8.3, \mathrm{H}-2), 0.56(1 \mathrm{H}, \mathrm{dd}, J=4.3,4.3 \mathrm{~Hz}, \mathrm{H}-3 \beta) ;{ }^{13} \mathrm{C}$ $\operatorname{NMR}\left(\mathrm{CDCl}_{3}, 150 \mathrm{MHz}\right) \delta 183.0(\mathrm{C}, \mathrm{C}-20), 171.5$ (C, OAc), 75.1 (CH, C-5), 52.0 (C, C-10), 51.7 (CH, C-14), $45.3(\mathrm{CH}$, C-13), 44.1 (CH, C-1), $42.3\left(\mathrm{CH}_{2}, \mathrm{C}-6\right), 36.8$ (C, C-7), 36.3 $\left(\mathrm{CH}_{2}, \mathrm{C}-11\right), 34.9\left(\mathrm{CH}_{2}, \mathrm{C}-8\right), 32.3\left(\mathrm{CH}_{2}, \mathrm{C}-9\right), 31.1(\mathrm{CH}$, $\mathrm{C}-15), 27.5\left(\mathrm{CH}_{2}, \mathrm{C}-12\right), 26.7(\mathrm{CH}, \mathrm{C}-2), 25.5\left(\mathrm{CH}_{3}, \mathrm{C}-18\right)$, $23.2\left(\mathrm{CH}_{3}, \mathrm{C}-17\right), 22.3\left(\mathrm{CH}_{3}, \mathrm{C}-16\right), 21.8\left(\mathrm{CH}_{2}, \mathrm{C}-3\right), 21.5$ $\left(\mathrm{CH}_{3}, \mathrm{OAc}\right), 20.1$ (C, C-4), $16.4\left(\mathrm{CH}_{3}, \mathrm{C}-19\right)$; negative ion HRESIMS: $m / z 361.2391$ (calcd for $\mathrm{C}_{22} \mathrm{H}_{33} \mathrm{O}_{4}[\mathrm{M}-\mathrm{H}]^{-}$, 361.2384).

\subsection{Antifungal Assay}

The minimum inhibitory concentration (MIC) of the fungistatic on hyphae was performed by incorporating the pure compound solutions $(12.5,25.0,50.0,100.0 \mu \mathrm{g} / \mathrm{mL})$ onto PYGS agar in a petri dish followed by inoculation of six tested fungal strains [21-23]. The MIC was determined visually as the lowest concentration showing no hyphal growth after they were incubated at $25{ }^{\circ} \mathrm{C}$ for 7 days.

Acknowledgements This research was financially supported by the Sabah Biodiversity Centre Grant (SaBC) [No. GL0070] and Universiti Malaysia Sabah (UMS) Grant [SBK0258-SG-2016]. The authors would like to thank Prof. Dr. Kishio Hatai (Borneo Marine Research Institute, UMS) for his kind guidance on bioassay. We are grateful to the Sabah Forestry Department for their support and assistance in the field. Finally, we were able to conduct research using literatures purchased through research project A provided by Shizuoka Institute of Science and Technology.

Funding This research was financially supported by SaBC Grant [No. GL0070] and UMS Grant [SBK0258-SG-2016].

\section{Compliance with Ethical Standards}

Conflict of interest The authors declare no conflict of interest.

Open Access This article is licensed under a Creative Commons Attribution 4.0 International License, which permits use, sharing, adaptation, distribution and reproduction in any medium or format, as long as you give appropriate credit to the original author(s) and the source, provide a link to the Creative Commons licence, and indicate if changes were made. The images or other third party material in this article are included in the article's Creative Commons licence, unless indicated otherwise in a credit line to the material. If material is not included in the article's Creative Commons licence and your intended use is not permitted by statutory regulation or exceeds the permitted use, you will need to obtain permission directly from the copyright holder. To view a copy of this licence, visit http://creativecommons.org/licenses/by/4.0/.

\section{References}

1. L. Hui, R.X. Xu, X.S. Zhang, T.T. Zhu, H.X. Lou, A.X. Cheng, Phytochemistry 159, 190-198 (2019)

2. Y. Asakawa, A. Ludwiczuk, J. Nat. Prod. 81, 641-660 (2018)

3. S.Y. Ng, T. Kamada, C.S. Vairappan, Rec. Nat. Prod. 11, 508$513(2017)$

4. S.Y. Ng, T. Kamada, M. Suleiman, C.S. Vairappan, Nat. Prod. Res. 32, 1832-1837 (2018)

5. S.Y. Ng, T. Kamada, C.S. Phan, M. Suleiman, C.S. Vairappan, Heterocycles 96, 1958-1965 (2018)

6. Y. Asakawa, A. Ludwiczuk, F. Nagashima, in Chemical Constituents of Bryophytes, ed. by A.D. Kinghorn. Progress in the Chemistry of Organic Natural Products, vol 95 (Springer, Vienna, 2013), p. 796

7. J. Wei, Y. Cheng, W.H. Guo, D.C. Wang, Q. Zhang, D. Li, J. Rong, J.M. Gao, Sci. Rep. 7, 8883-8896 (2017)

8. J. Wei, W.H. Guo, C.Y. Cao, R.W. Kou, Y.Z. Xu, M. Górecki, L.D. Bari, G. Pescitelli, J.M. Gao, Sci. Rep. 8, 2175-2189 (2018)

9. P.M. Dewick, Nat. Prod. Rep. 19, 181-222 (2002)

10. A. Matsuo, H. Nozaki, M. Nakayama, S. Hayashi, J. Chem. Soc. Chem. Commun. 5, 198-200 (1978)

11. C. Grammes, G. Burkhardt, M. Veith, V. Hugh, H. Becker, Phytochemistry 44, 1495-1502 (1997)

12. H.J. Liu, C.L. Wu, H. Becker, J. Zapp, Phytochemistry 53, 845-849 (2000) 
13. H. Shimogawa, T. Teruya, K. Suenaga, H. Kigoshi, Bull. Chem. Soc. Jpn. 78, 1345-1347 (2005)

14. A.J. Singh, J.D. Dattelbaum, J.J. Field, Z. Smart, E.F. Woolly, J.M. Barber, R. Heathcott, J.H. Miller, P.T. Northcote, Org. Biomol. Chem. 11, 8041-8051 (2013)

15. A. Spyere, D.C. Rowley, P.R. Jensen, W. Fenical, J. Nat. Prod. 66, 818-822 (2003)

16. A. Banerjee, B. Hamberger, Phytochem. Rev. 17, 81-111 (2018)

17. A. Rudi, Y. Kashman, J. Nat. Prod. 55, 1408-1414 (1992)

18. Y. Asakawa, M. Toyota, H. Tanaka, T. Hashimoto, D. Joulain, J. Hattori Bot. Lab. 78, 183-188 (1995)
19. T. Yosief, A. Rudi, Z. Stein, I. Goldberg, G.M.D. Gravalos, M. Schleyer, Y. Kashman, Tetrahedron Lett. 39, 3323-3326 (1998)

20. J.M. Ryan, Ph.D Dissertation, Victoria University of Wellington, 2007

21. T. Kamada, C.S. Phan, T. Hamada, K. Hatai, C.S. Vairappan, Nat. Prod. Commun. 13, 17-19 (2018)

22. T. Kamada, J. Kulip, K. Tani, C.S. Phan, K. Hatai, C.S. Vairappan, Rec. Nat. Prod. 12, 317-322 (2018)

23. K.J. Shamsudin, C.S. Phan, J. Kulip, K. Hatai, C.S. Vairappan, T. Kamada, J. Asian Nat. Prod. Res. 21, 435-441 (2019) 